\title{
Existency of Green Coconut Fruit (Cocos Nucifera Linn Var. Viridis) As a Sufi Education Media
}

\author{
Djoko Hartono', Qurrotul A'yun² , Himatul Aliyah ${ }^{3}$ \\ ${ }^{1}$ IAI Al-Koziny, Sidoarjo, Indonesia \\ ${ }^{2}$ Science Department, Universitas Negeri Surabaya, Indonesia \\ ${ }^{3}$ Islamic Building School of Jagad Alimussirry Surabaya, Indonesia
}

\begin{abstract}
Every word that is mentioned by Allah in the Qur'an, is related to giving lessons to humans or inviting people to think. In Al-Qur'an, Surah An-Nur:35, explained that the nature of Allah's light in the form of a parable, something that was known to the people at that time, namely the olive tree. Indonesian scholars interpret it as a coconut tree. This research uses literature study method with phenomenological analysis, functionalism analysis, and critical analysis . The results are coconut has an important meaning in Indonesian public belief. People believe that the coconut fruit is a symbol that represents the spiritual life of humans towards the divine. The use of the coconut fruit symbol has been used by Sufi scholars in delivering advice which is full of philosophical meanings. Each part of the coconut fruit has its meaning representing a spiritual journey to the divine. Coconut skin and coir as Sharia. The use of green coconut fruit as a medium for Sufi education is expected to provide Sufis with good and easy to understand learning so that Sufis can take the knowledge given by their teachers.
\end{abstract}

Keywords: coconut; symbol; spiritual

\section{INTRODUCTION}

Every creature created by Allah SWT always has benefits in this world. If in the Qur'an Allah mentions the word plants or the name of a certain type of plant, it is usually always related to giving lessons to humans or inviting people to think. This gives a signal to man that plants were created by God not only as a fulfillment of man's physical needs, but also to fulfill his intellectual and spiritual needs.

In the Al-Quran Surat An-Nur verse 35 Allah says: "Allah (Giver) light (to) the heavens and the earth. The parable of Allah's light, is like a hole that is not transparent, in which there is a large lamp. The lamp in the glass (and) the glass is as if a star (shining) is like a pearl, which is kindled with the oil of the blessed tree, (i.e.) the olive tree which grows neither in the east (of something) nor in the west (her), whose oil (alone) almost illuminates, although the fire does not touch it. Light above the light (layers), Allah guides His light who he wants, and Allah makes parables for humans, and Allah Knows all things "(Al-Qur'anul karim).

This verse, if understood more deeply, will explain the nature of God's light in the form of a parable, something that was known to the people at that time, namely the olive tree. The olive tree 
here is not an olive tree in a literal sense but is a symbol or parable. The sentence "Light on the light (layers), Allah guides to His light who He wants" is interpreted as the Apostles and the Saints because they are in the light and they are none other than the light of Allah SWT. Allah, with his compassion, guides people to His light, guides people to believe in His Messenger, takes all the lessons from the Messenger and applies them in everyday life.

Ulama in the homeland (Indonesia) tell about the nature as in Surah An-Nur:35 not in the form of an olive tree because people in the country do not know the olive tree at all, the scholars gave a parable about this nature in the form of a coconut. Coconut fruit comes from the coconut tree (Cocos Nucifera), which is a type of palm tree with one straight trunk where each part has a function, this is why the coconut tree is known as the tree of life. The term tree of life is given because every part of it can produce benefits for life (Waloeyo, 2013). According to another opinion, the reason it is called the tree of life is because the coconut fruit represents the spiritual journey of human life to the divine.

Coconut fruit is a unique fruit which contains $95 \%$ natural water which is still sterile and pure. This green coconut water has tremendous health benefits, because it contains enzymes that can break down toxic properties in the body (Barlina, 2004). Efforts to cleanse this poison if interpreted spiritually as an effort to cleanse oneself from sinful actions towards the divine, namely Allah SWT. The spirituality of coconut is also believed by other religions. One example in Hindu mythology and according to the Vedic Scriptures, the coconut is a "heavenly tree." It is said that Lord Vishnu brought coconut trees as a source of health, tranquility, long life, and peace. The coconut tree is considered sacred and plays an important role in all religious ceremonies (Anggraini, 2017; Jannah, 2020).

Coconut also has an important meaning in the occult beliefs of Javanese people. The Javanese people believe that the coconut fruit is a symbol that represents the spiritual life of humans towards the divine. The use of the coconut fruit symbol has been used by Sufi scholars in delivering advice which is full of philosophical meanings (Hartono, 2020). Each part of the coconut fruit has its own meaning representing a spiritual journey to the Divine. Previous scholars' said that God created this universe full of parables, for those whose minds and hearts are open, it will be easy to know the nature of the form of objects and name them according to His rahman and womb.

The extraordinary role of coconut in life both in health and spirituality is very interesting to study more deeply, so that in this study, the researcher will raise the title "The Philosophy of Coconut Fruit (Cocos Nucifera) in the Spiritual Perspective of Islam Kejawen and Hinduism".

\section{METHOD}

This research uses literature study method with phenomenological analysis, functionalism analysis and critical analysis. The sources used to compile this article include some literature on 
green coconut fruit, coconut fruit philosophy and Sufi spiritual journey to God, both Javanese, Indonesian, Arabic and English literature. This literature includes books, journal articles, theses, online articles, etc. Various sources of literature were analyzed so that data could be found about the existence of green coconut fruit as a Sufi education (Arikunto, 2009).

\section{RESULT AND DISCUSSION}

Coconut fruit is a fruit that is widely grown in Indonesia. Coconut fruit as we know it has a layer, starting from the outer shell, coconut husk, the hard shell to the meat filled with coconut milk. Coconut milk naturally decomposes easily, it must be processed first so that it can become oil. After becoming oil, then the coconut becomes "Immortal", long lasting (Barlina, 2004). The layered coconut fruit structure was used by ancient Sufis to explain religion and represent our spiritual journey to the Divine (Muniroh, dkk, 2019) This is based on the verses of the Koran in Surah An-Nur verse 35.

\section{The Use of Coconut Fruit in Interpreting Life}

Life is like a coconut. Some are unable to peel it so they are fooled into thinking that the coconut peel is just the fiber, some are willing to take the trouble to peel it, only incomplete so that they think that the nucleus of a coconut is the "shell" (shell), some peel it thoroughly until it opens the shell. and find the meat and water, the third is what actually managed to peel the nucleus from the coconut fruit (Thank god, 2012).

a. Peeling the coconut husk until it reaches the shell / shell

Coconut skin is defined as hissi life. Humans at this stage of life do not want to decipher the meaning of life so that they are deceived by the skin / shell of life. Humans who live a philosophical life of hissi, only dare when hungry, only move to satisfy their lust, only carry out activities to pursue popularity, but if Islam was colonized, he doesn't care and if the Islamic ummah is wronged, he is indifferent. There is absolutely no Jihad Fisabilillah agenda and no Ilallah da'wah schedule.

b. Peel the coconut shells until they reach the meat

In the second stage, namely peeling coconut shells. After being able to manage dhohir or coir properly, then you can see the name coconut shell. Coconut shells are interpreted as meaningful life. Humans who exist in this stage of life have been able to peel the meaning of life and find its essence but it is not complete, such as peeling a new coconut until its "shell" has stopped and says this is the point.

c. Peel the coconut meat until you find the water

In the third stage, opening the meat and finding coconut water. Coconut meat and water are interpreted as hissi life. Humans at this stage of life are able to peel the meaning of life and find its essence and are able to enjoy it with satisfaction, such as a coconut peeler that is able to peel it until it finds coconut meat and water. 


\section{The Philosophy of Green Coconut Fruit as a Media for Sufi Education}

A Sufi in his journey of life in the world, must be able to find the meaning of the symbol of this coconut fruit so that he can reach the level of Ma'rifatullah [6]. The specialty and uniqueness of this coconut fruit makes coconut fruit used as a symbol to provide learning and advice to Sufi candidates so that Sufi candidates can take knowledge from the meaning contained in each part of the coconut fruit (Untari).

a. The outer shell and coconut husk

The outer shell of a coconut can be described as sharia. Coconut skin functions to protect the inner layer, protecting against impact. The skin and coir also serve to spread the coconut fruit, when the coconut falls into the water or into the sea it will float. That is why coconuts can be found on uninhabited islands in the middle of the sea, the process of spreading is because coconuts float in the current and are stranded on isolated islands and then grow. The skin and coir have a very important position because they function as spreaders of coconut, as well as the Shari'a which functions to spread religion throughout the earth (Muda, 2003).

b. Coconut shell or bathok

The hard coconut shell is inside the skin and coconut husk can be compared to Tarekat, hard and also has no coconut milk in it, its function is to directly protect the coconut flesh from external disturbances. This coconut shell is a place to attach the coconut meat and also connects the coconut meat with the outer shell (Yusuf, 2018). This hard coconut shell can be penetrated with seriousness and istiqamah effort, this is different from the outer shell of coconut and coconut husk which is easier to penetrate and easier to find because it is visible. Coconut shells do not have meat, let alone coconut milk, so a person who only sticks to the tarekat without wanting to carry out dhikr, carries out Master's orders and istiqamah doing good deeds, just as he is on the outer shell, is the same as the Shari'a, does not get anything (Muda, 2003).

\section{c. Coconut meat}

Coconut meat is like Itself, there is kept the secret of spiritual immortality from humans. Rasulullah said "The essence is my residence", for 24 hours he was in the realm of nature because he had Nur Allah SWT in him. What He does fully is the "movement" of Allah that resides in Him (Muda, 2003).

\section{d. Coconut water}

Coconut water is clear, although a bit cloudy and has extraordinary properties, the core of the coconut is water, this symbolizes a perfect prostration before Him, as we know that the nature of water is prostration, where water flows always to a lower place. The coconut water level or makrifat in Islamic Sufism in Javanese or illuminative is the peak stage in spirituality seen from the structure of the coconut fruit, the person in this stage begins by finding a mirror that is very clear in our hearts so that we feel we don't have any ego, don't have a sense of belonging, everything. belong to Allah and return to Allah. 


\section{e. Coconut oil}

Oil can be obtained if the coconut has been processed, starting from peeling the skin to squeezing coconut milk from the coconut meat. In this coconut milk is stored oil which is eternal. Rasulullah said, "Makrifat is my secret", why is it a secret because it is in essence. As if oil will not emerge by itself without being processed first (Muda, 2003)..

Debates about God only occur at the sharia and tarekat stages, there are indeed hard, dry and no coconut milk let alone oil. Arguing over something that doesn't exist is a waste of energy, but humans do enjoy doing it. When it comes to the realm of nature and Makrifat, there is no more debate, there is no more showing greatness and strength because people who have arrived there are busy enjoying what they get, busy enjoying the beauty of the scenery that has never been in a lifetime. Because all have seen there will be no more debate, everything has become real.

\section{CONCLUSION}

The analysis of each part of the green coconut fruit shows that the parts of the coconut are able to represent the spiritual journey of man to God from the level of sharia to the level of ma'rifat. The use of green coconut fruit as a medium for Sufi education is expected to provide Sufis with good and easy to understand learning so that Sufis can take the knowledge given by their teachers.

\section{REFERENCES}

Anggraini, R., Ain, N., Adnan, S. (2017). Phytochemical identification and characterization of anthocyanins from green coconut coir. Journal of Agricultural Technology, 18(3).

Arikunto, S. (2009). Research And Development. Bandung: Alfabeta.

Barlina, Rindengan. (2004). The potential of young coconut fruit for health and processing. Indonesia Coconut and Palmae Research Institute, 2(2).

Hartono, Djoko. (2020). Become a Human Being Loyal Heart. Surabaya: Jagad 'Alimussirry Islamic Boarding School (Member of IKAPI)

Haryanto, Sindung. (2013). World Javanese Symbol. Yogyakarta: Kepel Press (Member of IKAPI)

Jannah, N. K. (2020). The Effect of reading water Ayatul Kursi on the germination lettuce plant (Lactuca sativa L.). Journal Intellectual Sufism Research (JISR), 2(2), 43-45.

Mastono. (2009). The essence of coconut fruit structure. Accessed on October 8, 2020. http://kanktono.blogspot.com/2009/09/hakekat-struktur-buah-kelapa.html

Muda, S. (2013). Understanding The Essence of God Through Coconut Fruit. Accessed on October 8, 2020. https://sufimuda.net/2013/07/19/mem]-hakikat-tuhan-lewat-kelapa/

Munirah and Totamu, Abdina. (2019). Implementation of Sufism Education in Islamic Education. FARABI (Journal of Constructive Thought in the Field of Philosophy and Da'wah), 16(2).

Sham. (2012). Learning from the Philosophy of Coconut Fruit. Accessed on 26 September 2020. https://www.kompasiana.com//belajar-dari-filosofi-buah-kelapa/

Thank God, M Amen. (2012). Sufi Healing: Therapy in Sufism Literature. Walisongo Journal, 20(2).

Thank God, Amen. (2003). Contextual Sufism, Solution to Human Problems. Yogyakarta: Student Library. Gratitude, Amen and Masyharudiddin. (2012). Intellectual Sufism. Semarang: Student Library. 
Untari, Ida. Without years. Young Coconut Water as Traditional and Scientific Medicine. Akper PKU Muhammadiyah Surakarta.

Waloeyo, S. (2013). Learning from Coconut Fruits. Accessed on 26 September 2020. https://semarngwaloeyo.wordpress.com/2013/07/22/belajar-kepada-buah-kelapa/

Yusuf, W. (2018). Philosophy of Coconut and Its Benefits. Accessed on 26 September 2020. https://wakidyusuf.wordpress.com/2018/05/23/filsafat-kelapa-dan- benefits/ 